\title{
The experience of community urban gardens: Social organization and food security
}

\section{A experiência das hortas urbanas \\ comunitárias: organização social \\ e segurança alimentar}

Joeli Silva de SOUZA ${ }^{1}$ (iD) 0000-0002-2336-3555

Ryzia de Cassia Vieira CARDOSO ${ }^{1}$ (D) 0000-0001-5292-713X

Lídice Almeida Arlego PARAGUASSÚ2 (D) 0000-0002-9224-7515

Sidione Ferreira dos SANTOS 3 (ID) 0000-0001-5550-8993

A B S T R A C T

\section{Objective}

To characterize Salvador-Bahia community gardens, with regard to social organization, work, supply and access to food, in line with the concept of Food Security.

\section{Methods}

A cross-sectional, exploratory study was carried out involving information collection, identification and selection of community gardens. Seven community gardens were located, although only five participated, with data collected through the application of semi-structured questionnaires, used with 13 horticulturists.

\footnotetext{
1 Universidade Federal da Bahia, Escola de Nutrição, Programa de Pós-Graduação em Alimentos, Nutrição e Saúde. Av. Araújo Pinho, 32, Canela, 40110-050, Salvador, BA, Brasil. Correspondence to: JS SOUZA. E-mail: <joelisouza@yahoo.com.br>.

2 Prefeitura Municipal de Salvador, Secretaria de Saúde, Vigilância em Saúde e Ambiental. Salvador, BA, Brasil.

3 Universidade Federal da Bahia, Faculdade de Farmácia, Programa de Pós-Graduação em Ciências dos Alimentos. Salvador, BA, Brasil.

Article based on the master thesis by JS SOUZA, entitled "Hortas urbanas comunitárias em Salvador - BA: organização, trabalho e alimentos". Universidade Federal da Bahia; 2018
}

How to cite this article

Souza JS, Cardoso RCV, Paraguassú LAA, Santos SF. The experience of community urban gardens: Social organization and food security. Rev Nutr. 2019;32:e180291. http://dx.doi.org/10.1590/1678-9865201932e180291 


\section{Results}

Most of the gardens (80.0\%) were located in popular neighborhoods and had been in place for less than five years; they operated with no land legalization $(80.0 \%)$, in assigned areas $(80.0 \%)$ and without any technical support (100.0\%). No social organization was available in most of the initiatives $(60.0 \%)$. The greatest difficulties included: lack of funding (80.0\%) and volunteers for work (80.0\%), as well as water use restrictions $(80.0 \%)$. The crops included different fruits and vegetables, for self-consumption $(80.0 \%)$, donation $(60.0 \%)$, and/or commercialization (40.0\%). Horticulturists included women $(50.0 \%)$ and men $(50.0 \%)$, mean age 44.8 years, education between illiterates (25.0\%) and upper level (37.5\%), rural migrants (50.0\%) and experienced farmers $(62.5 \%)$. Positive aspects included the production and access to natural food and the pleasure of working with earth.

\section{Conclusion}

Insufficient policies limited technical support and financing were observed in this segment, although there were contributions to the generation of work opportunities, supply and access to food. The study showed a strong link between community gardens and strategies to promote Food and Nutrition Security.

Keywords: Food and Nutrition Security. Food Offer. Food Supply. Poverty. Urban Agriculture.

\section{RE S U M O}

\section{Objetivo}

Caracterizar as hortas urbanas comunitárias de Salvador-Bahia, quanto à organização social, ao trabalho, à oferta e o acesso aos alimentos, em alinhamento ao conceito de Segurança Alimentar.

\section{Métodos}

Realizou-se estudo transversal, exploratório, envolvendo levantamento de informações, identificação e seleção das hortas comunitárias. Sete hortas comunitárias foram localizadas, das quais cinco participaram, com coleta de dados por meio da aplicação de questionários semiestruturados, junto a 13 horticultores.

\section{Resultados}

A maioria das hortas $(80,0 \%)$ localizava-se em bairros populares, tinha menos de cinco anos de existência, funcionava sem legalização da terra (80,0\%), em áreas cedidas (80,0\%) e sem apoio técnico (100,0\%). Observou-se ausência de organização social, na maioria das iniciativas (60,0\%). As maiores dificuldades incluíram: falta de financiamento (80,0\%), de voluntários para o trabalho $(80,0 \%)$ e limitações no uso da água $(80,0 \%)$. Os cultivos compreenderam variedades de frutas e hortaliças, destinadas ao autoconsumo $(80,0 \%)$, à doação $(60,0 \%)$, elou à comercialização (40,0\%). Os horticultores incluíram mulheres (50,0\%) e homens (50,0\%), média de idade de 44,8 anos, escolaridade entre analfabetos $(25,0 \%)$ e nivel superior (37,5\%), migrantes rurais $(50,0 \%)$ e com experiência na agricultura (62,5\%). Como aspectos positivos do trabalho, constaram a produção e o acesso a alimentos naturais e o prazer pelo trabalho com a terra.

\section{Conclusão}

Verificou-se insuficiência de políticas para o segmento, reduzido apoio técnico e financiamento, conquanto houvesse contribuições para a geração de trabalho, a oferta e o acesso aos alimentos. O estudo revelou forte vinculação entre hortas comunitárias e estratégias de promoção da Segurança Alimentar e Nutricional.

Palavras-chave: Segurança Alimentar e Nutricional. Oferta de Alimentos. Abastecimento de Alimentos. Pobreza. Agricultura Urbana.

\section{N T R O D U C T I O N}

Urban and Peri-urban Agriculture (UPA) has been identified as an initiative that can potentially respond to urban problems in different dimensions. In developing countries, UPA has persisted for food subsistence reasons, while in developed countries there are both constraints and growth, contributing to the strengthening of Food and Nutrition Security (FNS) and to healthier environment [1-3]. 
Despite the political and economic scenario, UPA initiatives have continued in Brazilian regions [4-6]. The observed challenges include: insufficient governmental financial and technical support, no ownership of the green areas, difficulties in the organization and social sustainability $[7,8]$.

In Salvador, one of the most economically and socially inequitable cities in this country, the Urban Agriculture activity (UA) has been described since its founding, highlighting the presence of urban gardens. In the city, the production of vegetables and medicinal herbs is predominant, mostly for self-consumption [9-11].

In this connection, this study aimed to characterize Salvador community gardens in terms of social organization, work, supply and access to food, in line with the FNS concept.

\section{METHOD S}

An exploratory quantitative cross-sectional study was carried out in the community gardens in Salvador, Bahia. The study did not include gardens established in public institutions (day-care centers, schools, shelters, houses of support, hospitals, etc.) and private organizations. The study was conducted between May 2017 and January 2018.

The study included three stages: (i) information collection with public agencies, associations and key informants to locate the gardens; (ii) identification and selection of community gardens; (iii) on-site visits and data collection.

For the location of the gardens, information and documents were collected from State agencies Department of Rural Development (SDR, Secretaria do Desenvolvimento Rural) and Municipal agencies, Environmental Health Surveillance (VISAMB, Vigilância em Saúde Ambiental), addressing: location of vegetable gardens in the city, persons in charge, measurement of production areas, types of activities/planted species, partnerships and funding.

In addition, a survey was carried out with key informants: representatives of the Conselho Nacional de Segurança Alimentar e Nutricional - Bahia (CONSEA, Food Security Council of Bahia), Permaculture Institute of Bahia, religious institutions (Archdiocese of São Salvador), Non-Governmental Organizations (Casa Mátria and Rede Moinho), researchers from the UPA area, as well as fruit and vegetable vendors of open-air markets in Salvador - São Joaquim, Largo 2 de Julho and Agroecological Fair of the Universidade Federal da Bahia (UFBA, Federal University of Bahia).

Based on the survey, seven community gardens were identified; their selection was based on the following inclusion criteria: active garden, within the city perimeter, with production and harvest of fruits and/or vegetables, and with the person in charge accepting to participate in the survey. As a result, gardens that had not yet been harvested were excluded. Using this protocol, out of the seven gardens identified, only five entered the sample, forming a convenience sample (non-probabilistic).

At this stage, in addition to the addresses obtained in the municipal registry and/or through key informants, the location of the vegetable gardens via Global Positioning System, Google Earth and the Google Maps (Washington, United States) was established.

In the in loco visits, interviews were conducted, using semi-structured questionnaires, with 13 horticulturists, including those in charge of the gardens and the horticulturalists involved. The questionnaires were previously tested in gardens of the metropolitan area, and covered two dimensions: the vegetable garden and the horticulturists. 
In each garden, a specific questionnaire about the vegetable garden was used with the horticulturist in charge, asking questions regarding the history of the activity; legalization; area used; crop characteristics; social organization; assistance from government programs; and marketing characteristics and/or donations. Another questionnaire was used with general questions about the activity, geared to the oldest horticulturists and included issues organized in the following blocks: socioeconomic identification; history of participation and work in the garden; access to food produced; and positive and negative aspects in the performance of work.

The planting areas identified in the in loco visits, originated a map developed through the program ArcGis version 10.1 (Redlands, California, United States) using Instituto Brasileiro de Geografia e Estatística (IBGE, Brazilian Institute of Geography and Statistics) data base and a base of the Companhia do Desenvolvimento Urbanos do Estado da Bahia (CONDER, Bahia State Urban Development Company), both of the year 2010, and the planting areas were identified with the subheadings: private/community, institutional, community or private.

The data of the two questionnaires entered the databank of the RStudio software (Boston, United States), version 3.0.1; a descriptive analysis of the quantitative (continuous and discrete) and qualitative (nominal and ordinary) variables, resulting in tables by means of frequency distribution (\%). For the photographic records an image composition was obtained using the Photo!Editor Program (Redmond, Washington, United States).

This study was approved by the UFBA Research Ethics Committee (Opinion No.2,385,408/2017). In order to protect the identification of the gardens and of the participants, the denomination "Community Garden" (CG) and sequential number were adopted, thus being referred to as: CG1, CG2, CG3, CG4 e CG5.

\section{RE S U L T S}

\section{Survey of information and location of gardens}

At the state level (SDR), there were records of Family Agriculture; however, there were no records in connection with urban agriculture. At the municipal level (VISAMB), records of the urban gardens were identified, consisting of 42 initiatives (41 private and one community).

In contact with key informants, the origin of most of the fruits and vegetables of cities of the interior was registered. According to the street retailers, urban agriculture activities have declined, and some said they knew "a few urban farmers".

From the set of information gathering and community gardening initiatives location, it was possible to visit 16 green areas (Figure 1), of which $75 \%(n=12)$ were active - seven of them worked in the community mode and five were private.

Out of the seven active community gardens (58.33\%), one vegetable garden had not yet been harvested and one refused to participate in the survey, due to a concern to give out information, and was therefore not included in the study. 


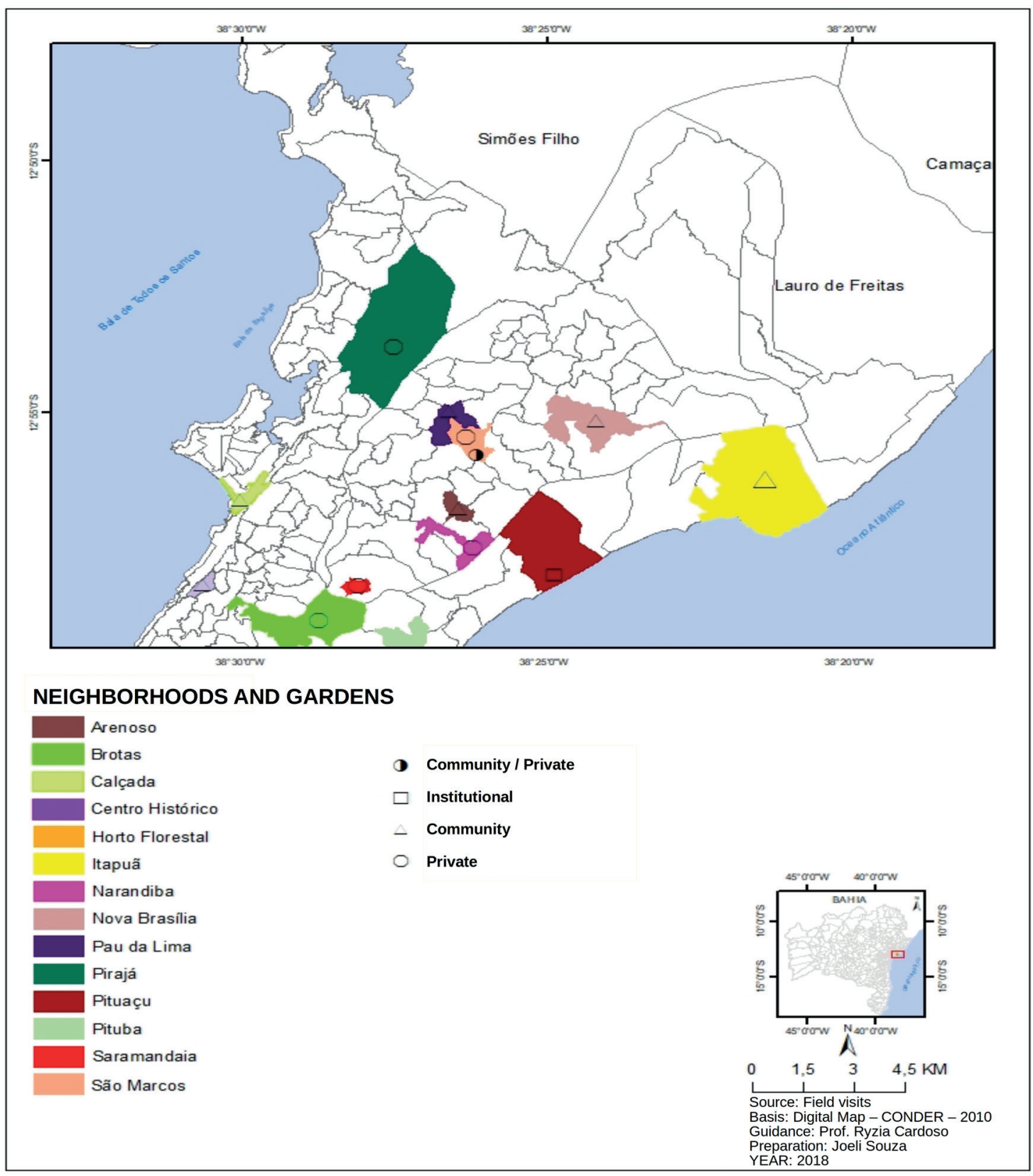

Figure 1. Areas (neighborhoods) visited with the indication of urban gardens. Salvador (BA), Brazil, 2017-2018.

Considering the historical division of the city into two altitude levels (Lower City and Upper City), it was found that out of the five active gardens, four (80\%) were located in Lower City (districts considered lower middle class, far from the city center and in peripheral areas). The other vegetable gardens (20\%) were in the Upper City (region of the upper class neighborhoods and near downtown).

Table 1 presents an initial characterization of the identified community gardens. As for social organization, although all gardens were of a community nature, in only two cases (40\%), there was an organized social structure, in the form of collective and religious community organization. 
Table 1. Characteristics of five community gardens. Salvador (BA), Brazil, 2017-2018.

\begin{tabular}{|c|c|}
\hline Characteristics & $(\%)$ \\
\hline \multicolumn{2}{|l|}{ Emergence } \\
\hline Community Initiative & 40 \\
\hline Religious initiative & 20 \\
\hline Initiative of public bodies & 40 \\
\hline \multicolumn{2}{|l|}{ Time of existence } \\
\hline $1-5$ years & 60 \\
\hline $5-10$ years & 0 \\
\hline 10 or more years & 40 \\
\hline \multicolumn{2}{|l|}{ Production interruption } \\
\hline Yes & 0 \\
\hline No & 100 \\
\hline \multicolumn{2}{|l|}{ Legalization of the area } \\
\hline Yes & 20 \\
\hline No & 80 \\
\hline \multicolumn{2}{|l|}{ Area of cultivation } \\
\hline Public agency & 60 \\
\hline Occupation / Invasion & 20 \\
\hline Others (Religious institution) & 20 \\
\hline \multicolumn{2}{|c|}{ How the use of the area happened } \\
\hline Loan & 80 \\
\hline Others (Invasion) & 20 \\
\hline \multicolumn{2}{|l|}{ Number of people } \\
\hline Up to 3 & 40 \\
\hline $11-15$ & 40 \\
\hline Above 20 & 20 \\
\hline \multicolumn{2}{|l|}{ Social organization } \\
\hline Yes & 40 \\
\hline No & 60 \\
\hline
\end{tabular}

In the in loco observations, the use of agrochemicals, chemical fertilizers or the like was not noticed. Standing out, CG3 maintained a specific area for composting, using tarpaulins and organic fertilizer preparation stages, as well as drying and grinding of pods, eggs and the use of ash.

In all the gardens, water was available, with $80 \%$ using it from the public water grid, and $60 \%$ water from the well, but without treatment. However, water supply is a limiting factor for the production and for continuation of the activities, which worsened during dry spells. In most of the gardens, there was no evidence of sewage and large volumes of waste.

All horticulturists reported that they did not receive any public technical assistance to perform their activities - the individuals most experienced in soil management tutored the new horticulturists.

As for the cultivation, all the community gardens of Salvador exhibited a great variety of fruits, leafy and non-leafy vegetables (Figure 2). No horticulturist processed his/her cultivated products. In natura foods were intended for self-consumption (80\%), donation (60\%) and marketing (40\%). 

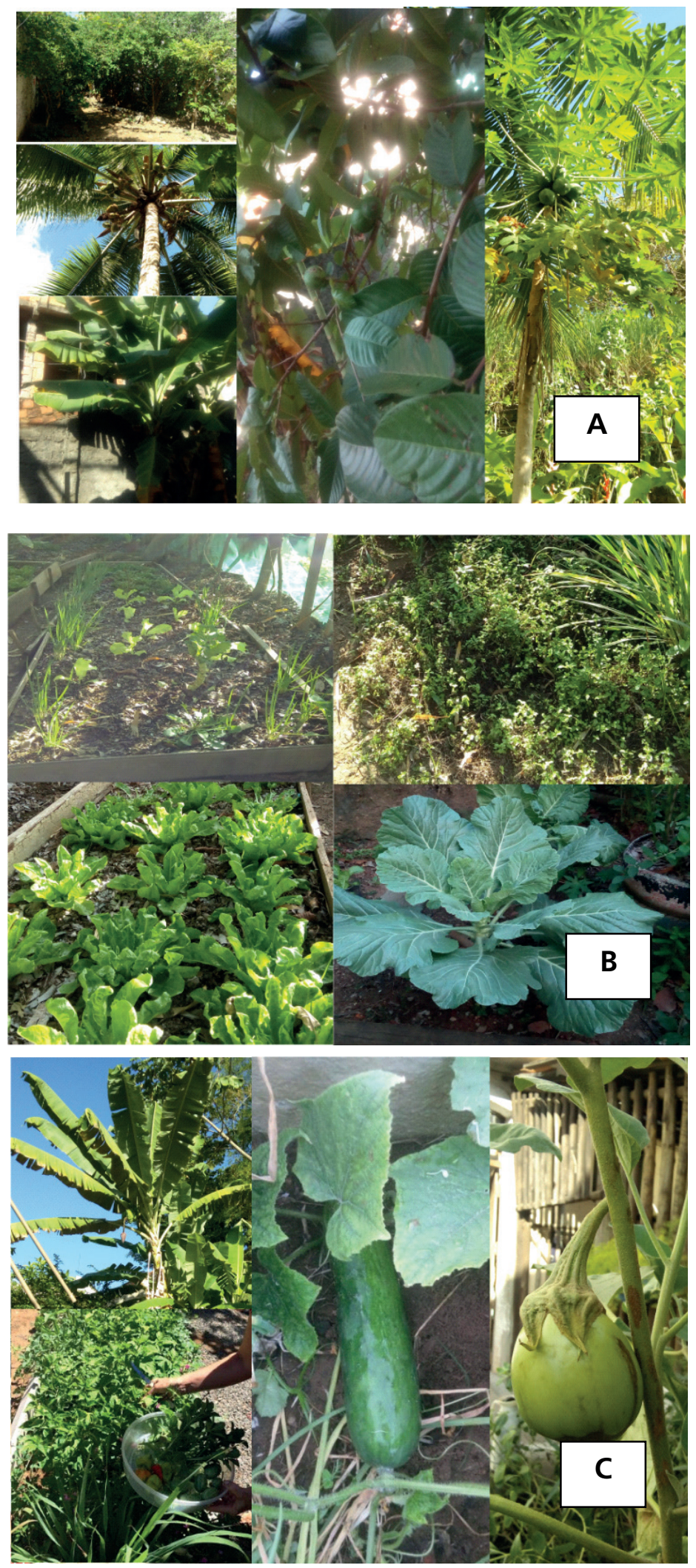

Figure 2. Types of crops found in community gardens: fruits (A), leafy vegetables (B), non-leafy vegetables (C). Salvador (BA), Brazil, 2017-2018. 
Regarding commercialization, 40\% of the gardens (CG4 and CG5) sold these products "in loco". The best-selling products included leafy vegetables (lettuce, Amazonian basil, coriander, arugula and kale) and roots/tubers (cassava and yam), and $40 \%$ of other products, such as medicinal herbs and ornamental plants. Every day, an average of 20 consumers visited CG4 and CG5.

Table 2 shows the socioeconomic characteristics of horticulturists involved in garden activities. Among the interviewees, there was a balanced participation of women and men in the economically active age range, with education ranging from illiteracy $(25.0 \%)$ to higher education $(37.5 \%)$, coming from the interior of the state $(50.0 \%)$ and from the city $(50.0 \%)$, with previous experience in the activity (62.5\%). Among them, 37.5\% were beneficiaries of the Bolsa Familia social program.

The link with the gardens generally originated from volunteer work, contact with the earth, satisfaction in the planting of natural products, the possibility of donation and self-consumption and the use of agroecological practices.

Table 2. Socioeconomic characteristics of horticulturists in urban community gardens. Salvador (BA), Brazil, $2017-2018$.

\begin{tabular}{|c|c|}
\hline Socioeconomic characteristics & $(\%)$ \\
\hline \multicolumn{2}{|l|}{ Gender } \\
\hline Female & 50.0 \\
\hline Male & 50.0 \\
\hline \multicolumn{2}{|l|}{ Age (year) } \\
\hline Average (range) & $44.8(25-60)$ \\
\hline \multicolumn{2}{|l|}{ Marital status } \\
\hline Single & 50.0 \\
\hline Married & 50.0 \\
\hline \multicolumn{2}{|l|}{ Education } \\
\hline Illiterate & 25.0 \\
\hline Elementary School & 12.5 \\
\hline High School & 25.0 \\
\hline Higher Education & 37.5 \\
\hline \multicolumn{2}{|l|}{ Householder } \\
\hline Yes & 12.5 \\
\hline No & 87.5 \\
\hline \multicolumn{2}{|l|}{ Origin } \\
\hline City & 37.5 \\
\hline Rural Zone & 0.0 \\
\hline State interior & 50.0 \\
\hline Other (foreign) & 12.5 \\
\hline \multicolumn{2}{|l|}{ Previous experience } \\
\hline Yes & 62.5 \\
\hline No & 37.5 \\
\hline \multicolumn{2}{|c|}{ Government aid - income transfer } \\
\hline Yes & 37.5 \\
\hline No & 62.5 \\
\hline
\end{tabular}


This characterization gave a distinct profile to the Salvador HCs, since studies in this field have reported educational level between illiteracy and elementary school, as well as the development of activities geared to commercialization and income generation [5-7].

With regard to the positive aspects of the gardens, the most cited were: natural food production, product diversity, community participation, joint decisions, location near the residence and work opportunity. The negative aspects included the lack of investments and training and irregular water supply.

\section{DISCUSSION}

In connection with the information gathering and identification of gardens, due to the absence or shortage of official records, public inaction and questioning are emphasized, regarding normative actions, organization, government, technical and financial support $[12,13]$, in addition to the impacts of urban expansion and the loss of urban agricultural land [3].

The experience of the UA has contributed to the enhancement of community life bonds $[4,14]$. In addition, the presence of associations and cooperatives can help the continuity of the initiatives, if they offer a participative management. Moreover, active participation in social movements provides a socializing and dynamic character of such productive urban spaces [14-16], and sustainability is determined by the agents involved [17].

Considering agroecological principles and practices found in community gardens, it is worth noting that successful experiences have been reported worldwide, with the Agroecological Fairs, Agroecology Joint efforts, Sustainability Projects, green manuring, among others [2,18-21].

The presence of a number of different fruits and vegetables in the gardens investigated shows alignment with the urban garden programs: use of horticultural production for own consumption, promotion of healthy eating habits, more balanced consumption practices with hortodiversity and agrobiodiversity management. [8,22,23].

Regarding the destination of the gardens' production, different actions were observed, from the perspective of the FNS: in the Upper City, it was geared mainly to donation to philanthropic institutions, while, in the Lower City, self-consumption prevailed.

It is pointed out that technical assistance is essential for the production of vegetables that involve organic cultivation [21], and this was absent in the gardens of Salvador, as well as in the UPA of other Brazilian regions, constituting a limitation of crop improvement $[1,7]$.

Horticulturists, mostly volunteers, were developing their activities collectively. The construction of these solidarity networks enhances the social ties between producers and consumers, the agro-ecological educational activities and the collective participation in the decisions $[2,15,20]$.

In some cases, the practice of urban agriculture appears to be intended for leisure, unrelated to work [15]. However, such an idea cannot be generalized, since UPA also is manual, informal and unpaid work.

The negative aspects found in this study are similar to those reported in research $[1,6,7]$, highlighting the need to expand resources for health promotion activities, garden maintenance and technical assistance. In spite of the difficulties, all the horticulturists felt satisfied with their contact with earth, with the production of food and with the established bonds. 
Thus, the findings in the community gardens indicate contributions to the FNS, through the production, supply and consumption of local food, reducing food shortages in communities facing poverty $[4,6,8]$.

As a positive aspect, the resilience of horticulturalists is emphasized, despite the difficulties regarding technical and financial support, and the low participation of the community. Another contribution of the study includes the update of results, which can add to the public records.

The main limitations included: the lack of official records, requiring time for active search and restricting the identification of vegetable gardens, during the study period; the gardens in areas difficult to access; and the refusal of some participants, including those in charge of the gardens and horticulturists who, due to previous conflict of interests with public inspection agencies, who were concerned on making available information on their activities.

\section{CONCLUSION}

Considering the objective and the methodology adopted, it was possible to show the insufficiency and lack of records on urban agriculture in the city, in the competent public agencies, raising the need for an active search of the planting areas.

Thus, it was common to verify limitations to the functioning and sustainability of the gardens, including the lack of land legalization, the difficulty of technical and financial support of the public agencies and the poor involvement and social organization of the residents.

At the same time, Salvador community gardens contributed to the access and provision of healthy food, in poverty-stricken neighborhoods, with production for self-consumption, commercialization and donation, with a lack of policy formulation for the segment, in the framework of Food and Nutrition Security promotion.

\section{CONTRIBUTORS}

JS SOUZA and RCV CARDOSO participated in the study development, data interpretation, and critical review of the manuscript, regarding intellectual content and final version. LAA PARAGUASSÚ contributed to the manuscript's critical review and supervision of field work. SF SANTOS helped in the article review.

\section{REFERENCES}

1. Costa CGA, Garcia MT, Ribeiro SM, Salandini MFS, Bógus CM. Hortas comunitárias como atividade promotora de saúde: uma experiência em Unidades Básicas de Saúde. Ciênc Saúde Coletiva. 2015;20(10):3099-110. http://dx.doi.org/10.1590/1413-812320152010.00352015

2. La Rosa D, Barbarossa L, Privitera R, Martinico F. Agriculture and the city: A method for sustainable planning of new forms of agriculture in urban contexts. Land Use Policy. 2014;41:290-303. http://dx.doi.org/10.1016/j. landusepol.2014.06.014

3. Mok HF, Williamson VG, Grove JR, Burry K, Barker SF, Hamilton AJ. Strawberry fields forever? Urban agriculture in developed countries: A review. Jan Agron Sustain. 2014;34:21-43. https://doi.org/10.1007/ s13593-013-0156-7

4. Schneider T, Niederle P, Vecchio-de LM. Agricultura urbana como crítica e alternativa: práticas comunicativas em torno da alimentação no contexto de crises socioambientais. RP. 2017 [citado 2019 jan 22];20(3_94):723-59. Disponível em: http://www.revistarazonypalabra.org/index.php/ryp/article/view/736 
5. Lobato G, Lucas F, Tavares-Martins A, Jardim M, Martorano L. Diversidade de uso e aspectos socioambientais de quintais urbanos em Abaetetuba, Pará, Brasil. Rev Bras Agroecol. 2017 [citado 2019 jan 22];12(2):95-105. Disponível em: http://revistas.aba-groecologia.org.br/index.php/rbagroecologia/article/view/16221

6. Albertin RM, Augusto DC, Mubai BA, Angelis BLD, Silva M, Silva FF, et al. Hortas urbanas de Maringá (PR): estudo socioeconômico dos produtores e perceptivo dos transeuntes. Bol Geogr. 2016;34(2):98-115. http:// dx.doi.org/10.4025/bolgeogr.v34i2.23600

7. Calbino D, Borges I, Andrade L, Abreu C, Gonçalves F. Avanços e desafios das hortas comunitárias urbanas de base agroecológica: uma análise do município de Sete Lagoas. Rev Desen Reg. 2017;14(2):61-80. http:// dx.doi.org/10.26767/coloquio.v14i2.718

8. Zaar M. A agricultura Urbana e Periurbana (AUP) no marco da soberania alimentar. Soc Ter. 2015 [citado 2019 jan 22];27(3):26-44. Disponível em: https://periodicos.ufrn.br/sociedadeeterritorio/article/view/7870

9. Santandreu A, Lovo IC. Panorama da agricultura urbana e periurbana no Brasil e diretrizes políticas para sua promoção: identificação e caracterização de iniciativas de AUP em regiões metropolitanas brasileiras: documento referencial geral, versão final. Belo Horizonte: Ministério do Combate à Fome. 2007 [citado 2017 mar 5]. Disponível em: http://www.agriculturaurbana.org.br/textos/panorama_AUP.pdf

10. Paraguassú LAA. A agricultura urbana como estratégia de sustentabilidade da cidade do Salvador, Bahia, Brasil [Tese]. Salamanca: Universidad de Salamanca; 2013 [citado 2017 ago 5]. Disponível em: https://dialnet. unirioja.es/servlet/tesis?codigo $=80964$

11. Fundação Instituto de Pesquisas Econômicas. Plano Salvador 500: relatório de caracterização atual. Salvador: Fundação Instituto de Pesquisas Econômicas; 2015 [citado 2017 ago 10]. Disponível em: http://www.cms. ba.gov.br/uploads/pddu/Caracterizacao\%20Atual.pdf

12. Prefeitura Municipal de Salvador (Bahia). Lei n9.069/2016. Dispõe sobre o Plano Diretor de Desenvolvimento Urbano do Município do Salvador - PDDU 2016 e dá outras providências. Salvador: Prefeitura de Salvador; 2016 [citado 2018 fev 24]. Disponível em: http://www.sucom.ba.gov.br/wp-content/uploads/2016/07/LEl-n.9.069-PDDU-2016.pdf

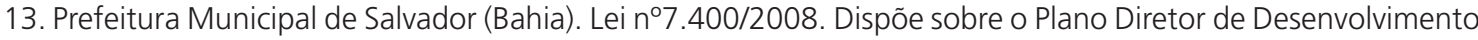
Urbano do Município do Salvador - PDDU 2007 e dá outras providências. Salvador: Prefeitura de Salvador; 2007 [citado 2017 mar 30]. Disponível em: http://www.sucom.ba.gov.br/wp-content/uploads/2014/11/ lei_7400_2008.pdf

14. Classens M. The nature of urban gardens: Toward a political ecology of urban agriculture. Agric Hum Values. 2015;32(2):229-39. http://dx.doi.org/10.1007/s10460-014-9540-4

15. Parada SP, Campoy MV, Gómez AJ. Determinación de los niveles de resiliencia/vulnerabilidad en iniciativas de agroecología urbana en el suroeste andaluz. Idesia. 2016;34(2):5-13. http://dx.doi.org/10.4067/S0718-3 4292016005000003

16. Codyre M, Fraser E, Landman K. How does your garden grow? An empirical evaluation of the costs and potential or urban gardening. Urban For Urban Gree. 2015;14(1):72-9. http://dx.doi.org/10.1016/j. ufug.2014.11.001

17. Winkler T, Álvarez F, Bertero D, Cruz P, Castillo C, Joffre R, et al. Calling for a reappraisal of the impact of quinoa expansion on agricultural sustainability in the Andean highlands. Idesia. 2014;32(4):95-100. http:// dx.doi.org/10.4067/S0718-34292014000400012

18. Brito PF, Mello MGS. Horta agroecológica como caminho para encontros. Cad Saúde Pública. 2016;32(11):1-2. http://dx.doi.org/10.1590/0102-311x00179816

19. Ribeiro SM, Bógus CM, Watanabe HAW. Agricultura urbana agroecológica na perspectiva da promoção da saúde. Saúde Soc. 2015;24(2):730-43. http://dx.doi.org/10.1590/S0104-12902015000200026

20. Enqvist J, Tengo M, Bodin Õ. Citizen networks in the Garden City: Protecting urban ecosystems in rapid urbanization. Landscape Urban Plan. 2014;130:24-35.

21. Sediyama MAN, Santos IC, Lima PC. Cultivo de hortaliças no sistema orgânico. Rev Ceres. 2014;61Supl:829-37. http://dx.doi.org/10.1590/0034-737x201461000008

22. Freire M, Ramos IJ. Solo agrícola e agricultura em espaço urbano: dinâmicas. O exemplo de Évora. GOT. 2014 [citado 2017 set 30];(6):113-34. Disponível em: http://cegot.org/ojs/index.php/GOT/article/ view/2014.6.008/91

23. Hunter AJ, Luck G. Defining and measuring the social-ecological quality of urban greenspace: A semi-systematic review. Urban Ecosyst. 2015;18(4):1139-63. http://dx.doi.org/10.1007/s11252-015-0456-6 